\title{
14. SEAWATER VENTILATION OF MID-PACIFIC GUYOTS DRILLED DURING LEG $143^{1}$
}

\author{
Charles K. Paull, ${ }^{2}$ Paul D. Fullagar, ${ }^{2}$ Timothy J. Bralower, ${ }^{2}$ and Ursula Röhl ${ }^{3}$
}

\begin{abstract}
Active exchange between guyot interior pore-waters and surrounding seawater is indicated by ${ }^{87} \mathrm{Sr} /{ }^{86} \mathrm{Sr}$ and $\delta^{18} \mathrm{O}$ values of pore waters and by ${ }^{87} \mathrm{Sr} /{ }^{86} \mathrm{Sr}$ values of their host carbonates, sampled from the interior of Allison (Site 865) and Resolution (Site 866) guyots. The ${ }^{87} \mathrm{Sr} /{ }^{86} \mathrm{Sr}$ values and strontium concentrations of the pore fluids are similar to modern seawater, rather than to their host carbonates. This requires that seawater flushing rates through most of these drowned Cretaceous carbonate platforms be adequate to keep the strontium in pore waters in guyots at or near equilibrium with modern seawater. However, some restriction in the seawater circulation is suggested, because $\delta^{18} \mathrm{O}$ values of pore waters from the pelagic-cap section of Site 865 are not like those of the surrounding seawater and because temperatures increase downhole at both guyots. These observations indicate that the current rate of fluid exchange within the Tertiary pelagic sediments that draped these guyots was slower than once every $10^{4}$ yr and may have been dominated by diffusion, whereas exchange in the uppermost, porous Mesozoic limestones beneath the drape was faster than once every $10^{4} \mathrm{yr}$. Fluid flushing rates decrease to once every $\sim 10^{6} \mathrm{yr}$ in the deeper, less porous limestones and altered basaltic basement below. Current flushing rates suggest that the upper porous shallow-water carbonate strata have been flushed by more than 10,000 pore volumes of seawater since they drowned ( $92 \mathrm{~m} . \mathrm{y}$. ago). Large flushing volumes may be an important part of the cementation and corrosion of these platforms.
\end{abstract}

\section{INTRODUCTION}

Residence times and chemical evolution of waters within carbonate platforms have a significant influence on the extent and nature of carbonate diagenesis. For example, where flushing rates are slow, the extent of diagenetic alterations may be limited by the rate of supply or removal of chemical species. However, with high flushing rates, large amounts of solute transport can provide or remove chemical constituents (Bathurst, 1975). The difficulty of obtaining the necessary water-to-rock ratios (e.g., Dunham, 1969) has been a complication for some models of dolomitization. Another consequence of significant flushing may be its role in the generation of secondary porosity and permeability in guyots and other carbonate platforms.

The extent to which the carbonate caps of these long-drowned guyots are open or closed geochemical systems is not known. One possibility is that interstitial waters still may be nearly identical to primary connate waters or, conversely, the interstitial fluids within porous limestones may have been flushed by many volumes of seawater since their formation. Here, we assess the extent of modern seawater flushing through these special types of carbonate structures and consider the geological implications of the flushing process.

\section{Fluid Movement in Analogous Carbonate Platforms}

Some modern carbonate platforms and atolls are known to have very fast flushing rates. In fact, fluids in boreholes in Anewetak and Pikinni are known to oscillate on a tidal frequency. The formation temperatures of these fluids remain close to those of the adjacent oceanic waters throughout $1200 \mathrm{~m}$ (Swartz, 1958; Ladd and Schlanger, 1960; Aharon et al., 1987; Rougerie and Wauthy, 1990). Apparently, the interstitial waters deep within these emergent atolls, which are morphologically similar to Allison and Resolution guyots, are in open communication with the ocean.

\footnotetext{
${ }^{1}$ Winterer, E.L., Sager, W.W., Firth, J.V., and Sinton, J.M., 1995. Proc. ODP, Sci. Results, 143: College Station, TX (Ocean Drilling Program).

${ }^{2}$ Geology Department, University of North Carolina at Chapel Hill, Chapel Hill, NC 27599-3315, U.S.A

${ }^{3}$ Brundesanstalt für Geowissenschaften und Rohstoffe, Postfach 510153, D-3000 Hannover 51, Federal Republic of Germany.
}

Conversely, the interior of large carbonate platforms of similar age and facies as Allison and Resolution guyots have been frequently associated with evolved pore-water compositions and even brines. For example, salinities of more than 200 parts per thousand (ppt) are known to have occurred within Aptian-Albian carbonates of the Florida-Bahama Platform in similar facies (Manheim and Horn, 1968). The formation of such saline fluids requires both long periods of time and restricted circulation.

Many of the driving forces that stimulate fluid flow in emergent atolls or larger carbonate platforms (e.g., tidal forces, wave pumping, small changes in the thermocline structure, hydrostatic heads associated with fresh water aquifers, and drainage associated with changes in sea level; Whitaker and Smart, 1990) do not apply to their drowned counterparts. However, flow may have been stimulated within guyots by (1) lateral thermal differences that are developed by heat flow through the core of the guyots, (2) perturbations in the oceanic water column structure related to currents that flow around and over these structures (Roden, 1987), (3) paleoceanographically induced changes in the adjacent oceanic water column structure, and (4) diagenetic changes that alter pore-water density.

\section{Geographic, Hydrologic, and Hydrographic Settings}

During Leg 143, boreholes were drilled into the tops of two guyots in the Mid-Pacific Mountains of the western Pacific Ocean. Site 865 was located on Allison Guyot at $18^{\circ} 26.41^{\prime} \mathrm{N}, 179^{\circ} 33.33^{\prime} \mathrm{W}$ at a depth of $1372 \mathrm{~m}$. Site 866 was located on Resolution Guyot at $21^{\circ} 19.95^{\prime} \mathrm{N}$, $174^{\circ} 18.84^{\prime} \mathrm{E}$ at a depth of $1518.9 \mathrm{~m}$.

ODP Sites 865 and 866 extended from the top of Allison and Resolution guyots through a thin section of Tertiary carbonate foraminiferal-nannofossil ooze (139.7 and $0.9 \mathrm{~m}$ thick, respectively) into a thick section of lithified Mesozoic shallow-water carbonates (down to 720.9 and $1,620 \mathrm{~m}$, respectively) before terminating in basalt (at 870.9 and $1,743.6 \mathrm{~m}$, respectively). The contact between the carbonates and the basalt appeared depositional (Sager, Winterer, Firth, et al., 1993).

The lithologies of the samples, rapid drilling rates, poor core recovery, and well log data all indicate that the upper several $100 \mathrm{~m}$ of the Mesozoic shallow carbonate platform section in both holes is very porous and potentially permeable. However, both holes were terminated above the level of the seafloor away from the guyots (Fig. 1). 


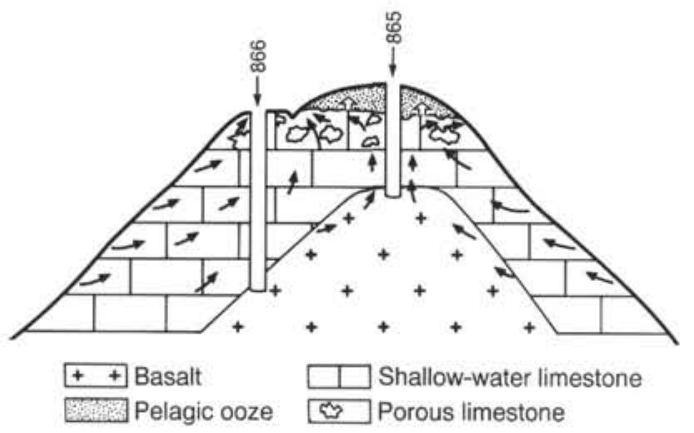

Figure 1. Schematic cross section showing the location of boreholes drilled at Allison (ODP Site 865) and Resolution (Site 866) guyots, with respect to an idealized guyot topography. The relationship to the pelagic carbonates (foraminiferal nannofossil oozes), shallow-water carbonates, and basaltic basement is indicated. The upper $\sim 600 \mathrm{~m}$ of the shallow-water carbonates are especially porous, as indicated with the cavernous porosity symbol. Note that the boreholes terminated at depths that were shallower than the seafloor surrounding these carbonate capped pedestals. Also indicated are potential pore-water flow lines.

Thus, fluid movements within these guyots might easily have involved exchange with the adjacent seawater through the flanks or exposed summits of these porous shallow-water carbonate edifices.

The hydrologic settings of Sites 865 and 866 differ in that Site 865 was drilled about $5.7 \mathrm{~km}$ away from the edge of the platform, while Site 866 was located only $2.4 \mathrm{~km}$ from its edge. In addition, the 139.7-m-thick pelagic-cap at Site 865 may have acted as an impermeable confining layer overlying the relatively permeable shallow-water limestones below. However, the pelagic-cap at Site 866 was of nominal thickness (<1 m)(Sager, Winterer, Firth, et al., 1993). The mid-Pacific waters that surround these guyots are about $4^{\circ} \mathrm{C}$ at the tops of these boreholes (Reed, 1969; Edmond et al., 1971) and decrease by more than $2^{\circ} \mathrm{C}$ over the $1671 \mathrm{~m}$ that was logged at Site 866 .

\section{Alteration History of the Carbonates}

The Mesozoic carbonates are well lithified and are composed of low-Mg calcite and lesser amounts of dolomite in some of the deeper cores. These lithologies indicate that a substantial amount of alteration occurred at some point in their history (Sager, Winterer, Firth, et al., 1993).

The pelagic-cap samples from Site 865 are unlithified and except for some dissolution have undergone little diagenetic alteration (Sager, Winterer, Firth, et al., 1993; Röhl et al., this volume).

\section{Shipboard Measurements and Observations}

Routine shipboard pore-water composition measurements (i.e., $\mathrm{Cl}^{-}, \mathrm{SO}_{4}^{2-}, \mathrm{NH}_{4}^{+}, \mathrm{Ca}^{2+}, \mathrm{Mg}^{2+}, \mathrm{Sr}^{2+}$ ) for the Cretaceous guyots drilled during Leg 143 show compositions that are mostly similar to seawater (Sager, Winterer, Firth, et al., 1993). However, the pore-waters from the Mesozoic shallow-water limestone contain less sulfate and some ammonium, indicating that minor compositional evolution of the sampled waters associated with microbial processes occurred. Shipboard $\mathrm{Sr}^{2+}$ data indicated that some samples had slightly lower $\mathrm{Sr}^{2+}$ concentrations than modern seawater. Unfortunately, with the shipboard data alone, we cannot distinguish whether the interiors of these guyots were relatively inert or were flushed rapidly with seawater.

\section{Strontium Isotopes as Tracers of Seawater vs. Connate Waters}

Strontium isotope stratigraphies are based on the observation that the ocean is well-mixed with respect to strontium and that carbonates, which form in ocean waters, reflect the isotopic composition of sea- water. At deposition, carbonates and the original pore-waters have the same isotopic values as seawater (e.g., Burke et al., 1982; Hess et al., 1986; Ludwig et al., 1988). However, long-term modifications in global chemical budgets slowly change the strontium isotopic composition of the ocean (Brass, 1976). The general trends of seawater strontium isotopic composition $\left({ }^{87} \mathrm{Sr} /{ }^{86} \mathrm{Sr}\right)$ are well known back through the Cretaceous (Hess et al., 1986) with values of Early Cretaceous seawater (as monitored by the carbonates) of $<0.707$ and modern seawater values of $>0.709$. Thus, by measuring differences between the ${ }^{87} \mathrm{Sr} /{ }^{86} \mathrm{Sr}$ values in pore waters and their host carbonates of known age, one can assess how much of the interstitial strontium is original and how much has been transported into the system (e.g., Baker et al., 1991; Elderfield et al., 1993).

The guyots drilled during Leg 143 are particularly good places to study flushing histories using strontium isotopes as a circulation tracer because (1) most of these carbonate-rich rocks have extremely low clay contents; thus, other sources of strontium that can make the interpretation of strontium isotope data equivocal in other settings (Elderfield and Gieskes, 1982) are reduced or eliminated and (2) the strontium isotopic compositions of the Lower Cretaceous carbonates and modern seawater are distinct, and changes between these two time periods have been essentially unidirectional.

\section{$\delta^{18} \mathrm{O}$ Values as Tracers of Seawater vs. Connate Waters}

$\delta^{18} \mathrm{O}$ values of oceanic waters are known to have changed with global ice volume (Shackleton and Opdyke, 1973; Schrag and DePaolo, 1993). Heavier values occurred during glacial periods and lighter values during interglacials. Because the Earth is now in an interglacial period, the average value of modern seawater is nearly at a minimum for the Quaternary. Thus, $\delta^{18} \mathrm{O}$ values of interstitial waters from within these guyots would be expected to differ from the seawater that surrounds them, unless the flushing was fast enough to have completely replenished these structures over the last $\sim 10,000 \mathrm{yr}$ since the last ice age.

\section{METHODS}

Pore waters were isolated from unlithified pelagic-cap samples and from lithified limestone samples. Analyses were conducted on seawater, pore waters, and the carbonates in the solid phases of samples from Sites 865 and 866.

\section{Pore Waters from Unlithified Samples}

${ }^{87} \mathrm{Sr}^{186} \mathrm{Sr}$ analyses were conducted on pore waters that had been squeezed from the sediments that came from the pelagic caps of these guyots: 15 samples from Allison (Site 865) and one sample from Resolution Guyot (Site 866) (Table 1). Whole-round sections of the sediments were cut from the cores shortly after recovery. These sediments were extruded from the core liners, and the exterior of the sediment section was cut away. Waters from this material were extracted with a hydraulic squeezer (Sager, Winterer, Firth, et al., 1993). ${ }^{87} \mathrm{Sr} /{ }^{86} \mathrm{Sr}$ analyses were done on two water samples (from the pelagic cap of Allison Guyot), collected in situ with the water sampling temperature probe (WSTP) (Table 1). Fourteen pore-water samples from the pelagic cap of Allison Guyot (Hole 865B) having sufficient water yields ( $>20 \mathrm{~mL}$ ) were also selected for $\delta^{18} \mathrm{O}_{\mathrm{H}_{2} \mathrm{O}}$ analyses (Table 1).

\section{Pore Waters from Lithified Samples}

${ }^{87} \mathrm{Sr} /{ }^{86} \mathrm{Sr}$ analyses were conducted on five pore-water samples from Allison Guyot and 19 pore-water samples from Resolution Guyot that had been squeezed directly from the platform limestones. None of these samples, however, came from the uppermost parts of the shallow-water limestones, where core recovery was lowest and where porosities (and permeabilities?) are thought to have been highest. 
Table 1. ${ }^{87} \mathrm{Sr} /{ }^{86} \mathrm{Sr}, \delta^{18} \mathrm{O}_{\mathrm{H}_{2} \mathrm{O}}$ and $\mathrm{Sr}$ concentration data in the unlithified Tertiary pelagic carbonates from Allison (Site 865) and Resolution (Site 866) guyots.

\begin{tabular}{|c|c|c|c|c|c|c|c|c|}
\hline \multirow{2}{*}{$\begin{array}{c}\begin{array}{c}\text { Core, section, } \\
\text { interval }(\mathrm{cm})\end{array} \\
\text { 143-865B- }\end{array}$} & \multirow[t]{2}{*}{$\begin{array}{l}\text { Depth } \\
\text { (mbsf) }\end{array}$} & \multicolumn{2}{|c|}{$\begin{array}{c}{ }^{87} \mathrm{Sr} /{ }^{86} \mathrm{Sr} \pm \text { error } \\
\text { carbonates }\end{array}$} & \multicolumn{2}{|c|}{$\begin{array}{l}{ }^{87} \mathrm{Sr} /{ }^{86} \mathrm{Sr} \pm \text { error } \\
\text { pore-waters }\end{array}$} & \multirow[t]{2}{*}{$\begin{array}{c}\delta^{18} \mathrm{O} \\
(\% \circ \\
\text { SMOW) }\end{array}$} & \multirow[t]{2}{*}{$\begin{array}{c}{[\mathrm{Sr}]} \\
\mathrm{CaCO}_{3} \\
(\mathrm{ppm})\end{array}$} & \multirow[t]{2}{*}{$\begin{array}{c}{[\mathrm{Sr}]} \\
\mathrm{H}_{2} \mathrm{O} \\
(\mathrm{ppm})\end{array}$} \\
\hline & & & & & & & & \\
\hline & 8.30 & 0.708770 & 0.000004 & 0.709150 & 0.000004 & 0.6 & 900.0 & 7.4 \\
\hline $2 \mathrm{H}-5,145-150$ & 15.95 & 0.707858 & 0.000005 & 0.709230 & 0.000005 & 0.4 & 662.2 & 7.5 \\
\hline $3 \mathrm{H}-6,145-150$ & 26.95 & 0.707791 & 0.000004 & 0.709090 & 0.000004 & 0.5 & 958.8 & 7.6 \\
\hline $4 \mathrm{H}-5,145-150$ & 34.95 & 0.707727 & 0.000005 & 0.709021 & 0.000005 & & 705.0 & 7.8 \\
\hline $5 \mathrm{H}-4,145-150$ & 42.95 & 0.707723 & 0.000004 & 0.709006 & 0.000004 & 0.4 & 704.3 & 8.2 \\
\hline $6 \mathrm{H}-5,145-150$ & 53.95 & 0.707751 & 0.000006 & 0.709131 & 0.000006 & 0.4 & 626.7 & 7.6 \\
\hline $7 \mathrm{H}-1,0-10^{\wedge}$ & 57.50 & & & 0.709196 & 0.000006 & 0.8 & & 7.5 \\
\hline $7 \mathrm{H}-2,145-150$ & 58.95 & 0.707796 & 0.000004 & 0.709106 & 0.000004 & & 607.6 & 8.0 \\
\hline $8 \mathrm{H}-5,145-150$ & 72.95 & 0.707793 & 0.000008 & 0.709150 & 0.000009 & & 556.5 & 7.5 \\
\hline $9 \mathrm{H}-5,145-150$ & 82.45 & 0.707755 & 0.000005 & 0.709169 & 0.000005 & 0.4 & 406.5 & 7.5 \\
\hline $10 \mathrm{H}-4,145-150$ & 90.45 & 0.707748 & 0.000005 & 0.709051 & 0.000005 & & 592.3 & 7.6 \\
\hline $12 \mathrm{H}-5,145-150$ & 110.95 & 0.707749 & 0.000004 & 0.709134 & 0.000004 & 0.3 & 608.6 & 10.5 \\
\hline $13 \mathrm{H}-5,145-150$ & 120.45 & 0.707773 & 0.000004 & 0.709092 & 0.000004 & 0.0 & 728.8 & 7.6 \\
\hline $14 \mathrm{H}-3,145-150$ & 126.95 & 0.707779 & 0.000007 & 0.709088 & 0.000007 & 0.1 & 621.0 & 7.6 \\
\hline $14 \mathrm{H}-5,147-150$ & 129.95 & 0.707848 & 0.000005 & 0.709141 & 0.000005 & -0.1 & 706.4 & 7.5 \\
\hline $15 \times-1,0-10^{n}$ & 132.00 & & & 0.709164 & 0.000006 & 0.0 & & 9.7 \\
\hline $15 X-1,145-150$ & 133.45 & 0.707822 & 0.000004 & 0.709143 & 0.000004 & -0.2 & 586.3 & 7.5 \\
\hline $15 X-2,145-150$ & 134.95 & 0.707843 & 0.000005 & 0.709122 & 0.000005 & -0.3 & 545.1 & 7.5 \\
\hline $\begin{array}{l}\text { 143-866A- } \\
\text { IR-2, 47-48 }\end{array}$ & 1.20 & 0.708845 & 0.000004 & 0.709163 & 0.000004 & & 887.9 & 7.3 \\
\hline
\end{tabular}

Notes: Identification of samples include ODP borehole, core and section numbers, interval downsection in cm, and meters below seafloor (mbsf) to the top of the sampled interval. ${ }^{87} \mathrm{Sr} /{ }^{86} \mathrm{Sr}$ values of the pelagic carbonates \pm analytical errors (one standard deviation internal precision), ${ }^{87} \mathrm{Sr} /{ }^{86} \mathrm{Sr}$ values of the pore-waters \pm analytical errors (one standard deviation internal precision), $\delta^{18} \mathrm{O}_{\mathrm{H}}$ o values, $\mathrm{Sr}$ concentrations in the carbonates, and $\mathrm{Sr}$ concentration in the pore waters also are given. Samples collected with the WSTP tool from within the pelagic-cap are indicated with $\uparrow$. Pore-water sample vials $12 \mathrm{H}-5$ and $15 \mathrm{X}-1$ were observed to be cracked before analysis, thus some evaporation may have occurred, causing increases in $\mathrm{Sr}$ concentration.

Surfaces of these Cretaceous shallow-water carbonate samples were too firm to cut away the exterior parts of the samples, which potentially are contaminated with seawater. To remove surface waters, the rocks were wiped with a paper towel. These cleaned rock samples were placed into a sturdy plastic bag and struck with a hammer until the rocks broke into less than cubic-centimeter-sized pieces. Pieces of rock then were picked up with tweezers and placed into the squeezing pistons. Hydraulic squeezing of about $30 \mathrm{~g}$ of these small pieces yielded from 1.5 to $5.5 \mathrm{~mL}$ of water. All pore-water samples for isotopic analysis were sealed in glass ampules for shipment to the laboratory.

\section{Solid-phase Samples}

${ }^{87} \mathrm{Sr} /{ }^{86} \mathrm{Sr}$ analyses were conducted on the carbonate that remained in the hydraulic squeezers (called squeeze cakes) from which porewaters were extracted. Additional solid-phase ${ }^{87} \mathrm{Sr} /{ }^{86} \mathrm{Sr}$ analyses were conducted on rock chips.

\section{${ }^{87} \mathrm{Sr} /{ }^{86} \mathrm{Sr}$ and $\delta^{18} \mathrm{O}$ Analytic Procedures}

Solid samples were removed from the sealed plastic bags in which they were stored, shaved with a razor blade to remove the exterior of the sample before about 5 to $10 \mathrm{mg}$ of clean shavings were placed into a 7-mL Savillex teflon vial. Pore-water samples were decanted from the sealed glass vials in which they were stored aboard the ship into teflon vials.

After weighing, $\mathrm{a}^{84} \mathrm{Sr}$ spike was added to all samples. One milliliter of 1 normal acetic acid prepared from Ultrex ultra-pure acetic acid was added, and the carbonate samples were placed on a hot plate for $1 \mathrm{hr}$ or less. The strontium-bearing liquid was removed with a pipette to separate any remaining insoluble materials before being evaporated to dryness. The samples were then re-acidified with dilute nitric acid. A strontium concentrate was obtained from these liquid samples by ion chromatographic techniques using a crown ether cation exchange resin (Sr Spec). Measurements were performed with a VG Sector 54 mass spectrometer in the Geology Department at the University of North Carolina at Chapel Hill. Values have been normalized to $86 / 88=$ 0.1194 using exponential normalization. During this study, we analyzed 104 splits of National Bureau of Standards strontium isotopic standard SRM-987. The average ${ }^{87} \mathrm{Sr} /{ }^{86} \mathrm{Sr}$ value was $0.710250 \pm$ 0.000011 (one standard deviation). The results for three to six (generally five) SRM-987 standards run in the same turret with unknowns were used to adjust the ${ }^{87} \mathrm{Sr} /{ }^{86} \mathrm{Sr}$ values for unknowns (i.e., 0.710250 was accepted as the correct value, and if the ${ }^{87} \mathrm{Sr} /{ }^{86} \mathrm{Sr}$ ratio for standards averaged 0.710245 , then 0.000005 was added to the ${ }^{87} \mathrm{Sr} /{ }^{86} \mathrm{Sr}$ ratio for each sample in the turret).

Sr concentrations were obtained using standard mass spectrometric isotope dilution techniques using ${ }^{84} \mathrm{Sr}$ spike. Replicate analyses of standard samples indicate that $\mathrm{Sr}$ measurements have accuracy and precision of better than $1 \%$ of the measured concentration.

Oxygen isotopic compositions of pore-waters were measured at Global Geochemistry. Samples for $\delta^{18} \mathrm{O}_{\mathrm{H}_{2} \mathrm{O}}$ measurement were prepared by equilibration with $\mathrm{CO}_{2}$ (Epstein and Mayeda, 1953; Wong and Klein, 1986) and were reported with an accuracy of $0.1 \%$.

Borehole temperature measurements were made in Holes $865 \mathrm{~A}$ and $866 \mathrm{~A}$ during logging runs. Temperature measurements were performed as the logging tool entered the hole (Sager, Winterer, Firth, et al., 1993).

\section{RESULTS}

\section{Strontium Isotopes: Seawater}

The mean ${ }^{87} \mathrm{Sr} /{ }^{86} \mathrm{Sr}$ value of five measurements of modern seawater is $0.709167 \pm 0.000012$ (Table 2) and agrees well with previously reported values for modern seawater (Table 3).

\section{Strontium Isotopes: Pelagic Sediments}

The uppermost pelagic carbonate sample from Allison Guyot, Site $865 \mathrm{~A}$ (interval $143-865 \mathrm{~A}-1 \mathrm{H}-6,80-85 \mathrm{~cm}$ ), at a depth of $8.30 \mathrm{~m}$ has $\mathrm{a}^{87} \mathrm{Sr} /{ }^{86} \mathrm{Sr}$ value of 0.708770 (Fig. 2A). This sample is Miocene in age (Sager, Winterer, Firth, et al., 1993). ${ }^{87} \mathrm{Sr} /{ }^{86} \mathrm{Sr}$ values were measured in one sample (143-865A-1R-02,47-48) from $1.20 \mathrm{~m}$ into the pelagic cap of Resolution Guyot (Hole 866B). This pelagic carbonate sample was assigned a late Pliocene age on the basis of its fossil content (a diverse Neogene assemblage that indicated reworking) and has a ${ }^{87} \mathrm{Sr} /{ }^{86} \mathrm{Sr}$ value of 0.708845 , while its pore water has a value of 0.709163 (Fig. 2B). All the remaining 15 carbonate samples from the 

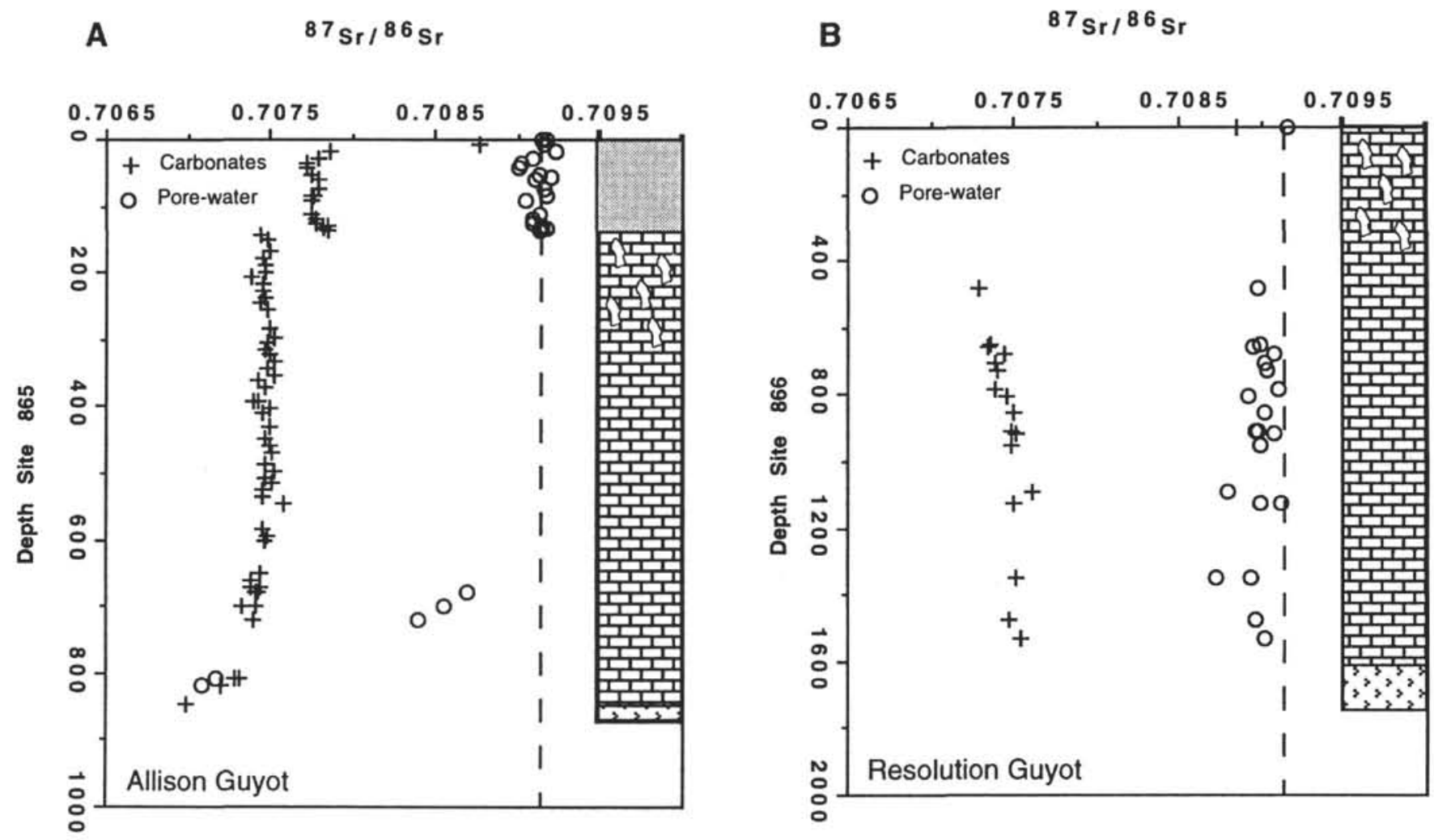

Figure $2 .{ }^{87} \mathrm{Sr}^{86} \mathrm{Sr}$ values that were measured in the carbonates (pluses) and their waters (circles) in Sites 865 (A) and 866 (B) vs. depth in the hole are shown. The idealized stratigraphic columns indicate the contacts between the pelagic and shallow-water carbonates and the contact between the shallow-water carbonates and basalt. Note that no samples were analyzed from the upper section of the shallow-water limestone units at Site 866, which are suspected of being very porous (indicated by schematic voids in the stratigraphic column). Dashed line indicates the modern ${ }^{87} \mathrm{Sr} /{ }^{86} \mathrm{Sr}$ value of seawater.

pelagic cap at Site 865 are Paleogene in age and vary in ${ }^{87} \mathrm{Sr} /{ }^{86} \mathrm{Sr}$ values from 0.707723 to 0.707858 (Fig. 2A). The pore waters in all 16 pelagic carbonate samples and from two samples collected in situ with the WSTP from Site 865 vary from 0.709006 to 0.709230 , with a mean value of $0.709213 \pm 0.000057$.

\section{Strontium Isotopes: Shallow-water Carbonate Sediments}

The values of all 56 shallow-water carbonate samples that were measured from Hole $865 \mathrm{~A}$ vary from 0.706991 to 0.707644 (Fig. 2A). $\mathrm{The}^{87} \mathrm{Sr} /{ }^{86} \mathrm{Sr}$ values of 19 shallow-water carbonate samples from Hole $866 \mathrm{~A}$ vary from 0.707291 to 0.707617 (Fig. 2B). Most of the slightly larger variation in Site 865 samples relative to Site 866 samples comes from the lowest four samples, in which the $\mathrm{CaCO}_{3}$ percentages decrease to $82 \%$ to $94 \%$.

The five pore-water samples available for ${ }^{87} \mathrm{Sr} /{ }^{86} \mathrm{Sr}$ analysis from within the shallow-water carbonates of Hole $865 \mathrm{~A}$ show a considerable trend toward lower ${ }^{87} \mathrm{Sr} /{ }^{86} \mathrm{Sr}$ values downcore (from 0.708698 at $679.70 \mathrm{~m}$ to 0.707090 at $816.82 \mathrm{~m}$; Fig. $2 \mathrm{~A}$ ). The deepest two porewater samples have ${ }^{87} \mathrm{Sr} /{ }^{86} \mathrm{Sr}$ values of less than their host carbonates. The available pore-water samples ( 22 measurements on 18 samples) for ${ }^{87} \mathrm{Sr} /{ }^{86} \mathrm{Sr}$ analysis from within the shallow-water carbonates of Hole $866 \mathrm{~A}$ vary from 0.708722 to 0.709109 (Fig. 2B).

\section{Strontium Concentrations: Pore-waters}

The Sr concentrations that were measured by isotope dilution on all 51 pore-water samples only ranged from 4.2 to $14.2 \mathrm{ppm}$, with a mean value of $7.5 \pm 1.5 \mathrm{ppm}$. The range of measured $\mathrm{Sr}$ concentration in the samples with uncracked vials from the pelagic cap was even smaller: 7.4 to $8.2 \mathrm{ppm}$, with a mean of $7.6 \pm 0.2 \mathrm{ppm}$. The values of the five samples of surface seawater ranged from 7.1 to $7.3 \mathrm{ppm}$ with a mean value of $7.22 \pm 0.08 \mathrm{ppm}$. Some of the slight difference between the surface and pore waters can be explained by the relatively low salinities of the North Pacific surface waters.

The pore-water $\mathrm{Sr}$ concentrations in 27 samples from the shallowwater carbonates range from 4.2 to $14.2 \mathrm{ppm}$ and have a mean value of $7.3 \pm 2.0 \mathrm{ppm}$. The samples having the highest $\mathrm{Sr}$ concentrations $(13.2$ and $14.2 \mathrm{ppm}$ ) came from the base of Hole 865A, near the basaltic basement. Excluding these samples, the remaining 25 samples have pore-water values that range between 4.2 and $8.3 \mathrm{ppm}$, with a mean value of $6.8 \pm 0.8 \mathrm{ppm}$. While the scatter in these samples is greater than in the pelagic-cap samples, they (as a group) also are indistinguishable from seawater.

The Sr concentrations that were measured on shipboard were similar to the more precise isotopic dilution values of this study. Specifically, shipboard analyses report a general decrease of $\mathrm{Sr}$ concentrations below seawater values with increasing depth in Hole $866 \mathrm{~A}$ and $\mathrm{a} \mathrm{Sr}$ concentration of about $4 \mathrm{ppm}$ for Section 143-866A-162R-1 (same as the isotope dilution value).

\section{Strontium Concentrations: Carbonates}

Carbonate from the pelagic-cap samples of both Holes $865 \mathrm{~A}$ and $866 \mathrm{~B}$ had strontium concentrations that ranged from 406.5 to $958 \mathrm{ppm}$ with a mean value of $656 \pm 145 \mathrm{ppm}(n=18)$. The $\mathrm{Sr}$ concentrations for the stratigraphically deeper shallow-water carbonates ranged from 92 to $631 \mathrm{ppm}$ with a mean value of $212 \pm 90 \mathrm{ppm}(n=73)$.

\section{Pore-water $\delta^{18} \mathrm{O}_{\mathrm{H}_{2} \mathrm{O}}$ Values}

$\delta^{18} \mathrm{O}_{\mathrm{H}, \mathrm{O}}$ values from the pore waters in the pelagic cap of Allison Guyot (Hole 865B) vary from -0.3 to $0.8 \%$ and have a mean value of $0.24 \pm 0.32 \%$ SMOW. The $\delta^{18} \mathrm{O}$ value of modern Pacific Ocean deep 
Table $2 .{ }^{87} \mathrm{Sr} /{ }^{86} \mathrm{Sr}$ values and $\mathrm{Sr}$ concentration data in the lithified Mesozoic shallow-water carbonates from and Allison (Site 865) and Resolution (Site 866) guyots.

\begin{tabular}{|c|c|c|c|c|c|c|c|}
\hline \multirow{2}{*}{$\begin{array}{l}\begin{array}{l}\text { Core, section, } \\
\text { interval }(\mathrm{cm})\end{array} \\
143-865 \mathrm{~A}-\end{array}$} & \multirow[t]{2}{*}{$\begin{array}{l}\text { Depth } \\
\text { (mbsf) }\end{array}$} & \multicolumn{2}{|c|}{$\begin{array}{l}{ }^{87} \mathrm{Sr} /{ }^{86} \mathrm{Sr} \pm \text { error } \\
\text { carbonates }\end{array}$} & \multicolumn{2}{|c|}{$\begin{array}{c}{ }^{87} \mathrm{Sr}{ }^{86} \mathrm{Sr} \pm \text { error } \\
\text { pore water }\end{array}$} & $\begin{array}{c}{[\mathrm{Sr}]} \\
\mathrm{CaCO}_{3} \\
(\mathrm{ppm})\end{array}$ & $\begin{array}{c}{[\mathrm{Sr}]} \\
\mathrm{H}_{2} \mathrm{O} \\
(\mathrm{ppm})\end{array}$ \\
\hline & & & & & & & \\
\hline $\begin{array}{l}\text { 18R-CC, 12-14* } \\
\text { 19R-CC, } 01^{*}\end{array}$ & $\begin{array}{l}144.82 \\
149.40\end{array}$ & $\begin{array}{l}0.707439 \\
0.707483\end{array}$ & $\begin{array}{l}0.000004 \\
0.000004\end{array}$ & & & $\begin{array}{l}153.6 \\
174.7\end{array}$ & \\
\hline $21 \mathrm{R}-\mathrm{CC}, 2-3^{*}$ & $\begin{array}{l}147.40 \\
168.82\end{array}$ & 0.707501 & 0.000006 & & & $\begin{array}{l}174.7 \\
139.8\end{array}$ & \\
\hline $22 \mathrm{R}-\mathrm{CC}, 12-13^{*}$ & 178.52 & 0.707456 & 0.000004 & & & 154.9 & \\
\hline 23R-CC, 5-6** & 188.05 & 0.707464 & 0.000004 & & & 188.1 & \\
\hline 24R-CC, 3-4* & 197.73 & 0.707464 & 0.000004 & & & 197.7 & \\
\hline 25R-CC, 1-2* & 207.31 & 0.707391 & 0.000004 & & & 174.2 & \\
\hline 26R-CC, $0-1^{*}$ & 217.00 & 0.707457 & 0.000004 & & & 169.4 & \\
\hline $27 \mathrm{R}-\mathrm{CC}, 0^{-1 *}$ & 226.60 & 0.707460 & 0.000004 & & & 182.3 & \\
\hline 28R-CC, 12-14* & 237.73 & 0.707469 & 0.000004 & & & 180.9 & \\
\hline 29R-CC, 3-4* & 245.93 & 0.707442 & 0.000004 & & & 138.5 & \\
\hline 30R-CC, $2-3^{*}$ & 255.62 & 0.707488 & 0.000004 & & & 186.7 & \\
\hline $32 \mathrm{R}-\mathrm{CC}, 14-16^{*}$ & 370.94 & 0.707463 & 0.000004 & & & 177.9 & \\
\hline 33R-CC, 2-3* & 284.62 & 0.707494 & 0.000004 & & & 172.8 & \\
\hline $34 \mathrm{R}-01,130-132 *$ & 295.50 & 0.707530 & 0.000007 & & & 185.2 & \\
\hline $35 \mathrm{R}-\mathrm{CC}, 0-2^{*}$ & 303.50 & 0.707478 & 0.000004 & & & 166.9 & \\
\hline $36 \mathrm{R}-\mathrm{CC}, 21-22 *$ & 313.31 & 0.707469 & 0.000004 & & & 153.6 & \\
\hline 37R-CC, $6-8 *$ & 322.86 & 0.707502 & 0.000004 & & & 172.4 & \\
\hline $38 \mathrm{R}-\mathrm{CC}, 9-11^{*}$ & 332.49 & 0.707521 & 0.000005 & & & 128.7 & \\
\hline $39 \mathrm{R}-\mathrm{CC}, 42-43^{*}$ & 342.32 & 0.707485 & 0.000004 & & & 153.9 & \\
\hline $40 \mathrm{R}-\mathrm{CC}, 35-36^{*}$ & 351.95 & 0.707528 & 0.000004 & & & 216.3 & \\
\hline $41 \mathrm{R}-\mathrm{CC}, 8-9^{*}$ & 361.28 & 0.707432 & 0.000004 & & & 168.4 & \\
\hline $42 \mathrm{R}-\mathrm{CC}, 14-16^{*}$ & 370.94 & 0.707476 & 0.000004 & & & 165.1 & \\
\hline $44 \mathrm{R}-\mathrm{CC}, 11-12^{*}$ & 390.21 & 0.707422 & 0.000004 & & & 542.4 & \\
\hline $44 \mathrm{R}-\mathrm{CC}, 11-12^{*}$ & 390.21 & 0.707402 & 0.000004 & & & 437.9 & \\
\hline $45 \mathrm{R}-\mathrm{CC}, 15-17^{*}$ & 400.50 & 0.707496 & 0.000004 & & & 148.7 & \\
\hline $46 \mathrm{R}-\mathrm{CC}, 3-5^{*}$ & 409.63 & 0.707462 & 0.000004 & & & 195.4 & \\
\hline 48R-CC, $1-3^{*}$ & 428.91 & 0.707491 & 0.000004 & & & 168.9 & \\
\hline & 448.01 & 0.707471 & 0.000004 & & & 163.9 & \\
\hline 51R-CC, 7-9* & 457.67 & 0.707503 & 0.000004 & & & 160.9 & \\
\hline 52R-CC, $13-15^{*}$ & 467.43 & 0.707515 & 0.000004 & & & 147.8 & \\
\hline $54 R-C C, 1-3 *$ & 486.61 & 0.707463 & 0.000004 & & & 170.3 & \\
\hline $55 \mathrm{R}-\mathrm{CC}, 7-8^{*}$ & 496.37 & 0.707528 & 0.000004 & & & 152.0 & \\
\hline 56R-CC, $41-42 *$ & 506.31 & 0.707469 & 0.000004 & & & 160.6 & \\
\hline 57R-CC, 12-13* & 515.62 & 0.707515 & 0.000004 & & & 161.5 & \\
\hline 58R-CC, 25-27* & 525.45 & 0.707452 & 0.000004 & & & 184.1 & \\
\hline 59R-CC, 8-10* & 534.88 & 0.707461 & 0.000004 & & & 160.2 & \\
\hline 60R-CC, $2-4^{*}$ & 544.52 & 0.707580 & 0.000004 & & & 170.2 & \\
\hline $64 \mathrm{R}-\mathrm{CC}, 17-20^{*}$ & 583.27 & 0.707451 & 0.000004 & & & 200.8 & \\
\hline 65R-CC, 3-4* & 592.83 & 0.707479 & 0.000005 & & & 215.7 & \\
\hline 66R-CC, $18-19 *$ & 602.28 & 0.707468 & 0.000004 & & & 189.7 & \\
\hline 7IR-CC, $6-7^{*}$ & 650.86 & 0.707438 & 0.000004 & & & 210.5 & \\
\hline $72 \mathrm{R}-\mathrm{CC}, 6-7^{*}$ & 660.46 & 0.707390 & 0.000005 & & & 488.8 & \\
\hline $73 \mathrm{R}-1,18-20^{*}$ & 670.28 & 0.707435 & 0.000004 & & & 194.4 & \\
\hline $73 R-1,73-75$ & 670.83 & 0.707388 & 0.000004 & & & 213.0 & \\
\hline $74 \mathrm{R}-1,0-5$ & 679.70 & 0.707412 & 0.000004 & 0.708698 & 0.000004 & 208.1 & 7.3 \\
\hline $74 \mathrm{R}-1,13-14^{*}$ & 679.83 & 0.707433 & 0.000004 & 8.1 .0070 & T.00000 & 221.1 & . \\
\hline $76 \mathrm{R}-1,40-41^{*}$ & 699.50 & 0.707336 & 0.000004 & & & 246.5 & \\
\hline $76 \mathrm{R}-1,70-75$ & 700.21 & 0.707411 & 0.000004 & 0.708554 & 0.000005 & 93.3 & 6.9 \\
\hline $78 \mathrm{R}-1,70-75$ & 719.10 & 0.707403 & 0.000007 & 0.708392 & 0.000004 & 166.8 & 7.6 \\
\hline $87 \mathrm{R}-3,51-54$ & 807.37 & 0.707289 & 0.000005 & 0.707176 & 0.000004 & 245.6 & 13.2 \\
\hline $87 \mathrm{R}-3,51-54$ & 807.37 & 0.707312 & 0.000004 & & & 255.0 & \\
\hline $88 \mathrm{R}-2,27-32$ & 816.82 & 0.707205 & 0.000004 & 0.707090 & 0.000004 & 631.0 & 14.2 \\
\hline IR-4, 61-66* & 845.97 & 0.706991 & 0.000004 & & & 200.7 & \\
\hline 143-866A- & & & & & & & \\
\hline $53 \mathrm{R}-1,41-42$ & 483.11 & 0.707291 & 0.000007 & 0.708974 & 0.000004 & 213.5 & 6.9 \\
\hline $70 \mathrm{R}-2,76-80$ & 648.47 & 0.707363 & 0.000007 & 0.708987 & 0.000004 & 233.7 & 7.0 \\
\hline 7IR-1, 12-14 & 656.50 & 0.707337 & 0.000009 & 0.708939 & 0.000004 & 212.8 & 6.5 \\
\hline $73 R-1,13-16$ & 675.93 & 0.707438 & 0.000006 & 0.709066 & 0.000004 & 224.6 & 6.6 \\
\hline $76 \mathrm{R}-1,53-56$ & 705.23 & 0.707386 & 0.000012 & 0.709017 & 0.000004 & 204.8 & 6.8 \\
\hline 78R-2, 105-111 & 726.54 & 0.707403 & 0.000005 & 0.709030 & 0.000004 & 262.2 & 6.4 \\
\hline $84 \mathrm{R}-1,42-45$ & 782.62 & 0.707385 & 0.000005 & 0.709100 & 0.000004 & 199.1 & 7.0 \\
\hline $86 \mathrm{R}-1,86-89$ & 802.36 & 0.707449 & 0.000004 & 0.708915 & 0.000004 & 220.5 & 6.2 \\
\hline $91 \mathrm{R}-1,104-107$ & 850.54 & 0.707494 & 0.000006 & 0.709017 & 0.000004 & 213.5 & 6.8 \\
\hline $97 \mathrm{R}-1,33-36 \dagger$ & 907.73 & 0.707487 & 0.000005 & 0.708975 & 0.000004 & 364.9 & 7.1 \\
\hline $97 \mathrm{R}-1,33-36$ & 907.73 & & & 0.708975 & 0.000004 & & 7.3 \\
\hline $97 \mathrm{R}-1,33-36$ & 907.73 & & & 0.708966 & 0.000005 & & 8.3 \\
\hline $98 \mathrm{R}-1,11-16$ & 917.11 & 0.707514 & 0.000004 & 0.709066 & 0.000004 & 241.2 & 7.0 \\
\hline $102 \mathrm{R}-1,16-20$ & 952.86 & 0.707485 & 0.000004 & 0.708982 & 0.000004 & 259.6 & 6.5 \\
\hline $116 \mathrm{R}-1,22-27 \dagger$ & 1087.72 & 0.707617 & 0.000004 & 0.708787 & 0.000004 & 294.8 & 7.1 \\
\hline $116 \mathrm{R}-1,22-27$ & 1087.72 & & & 0.708791 & 0.000005 & & 7.1 \\
\hline $120 \mathrm{R}-1,34-38+$ & 1126.44 & 0.707492 & 0.000004 & 0.708991 & 0.000005 & 272.0 & 7.4 \\
\hline $120 \mathrm{R}-1,34-38$ & 1126.44 & $0.70+472$ & . & 0.709109 & 0.000004 & 20.0 & 6.8 \\
\hline $143 \mathrm{R}-1,90-93$ & 1348.80 & 0.707514 & 0.000004 & 0.708722 & 0.000004 & 301.0 & 7.8 \\
\hline $143 \mathrm{R}-1,90-93+$ & 1348.80 & . & $0.00000 \mathrm{~T}$ & 0.708930 & 0.000004 & J01.0 & 5.7 \\
\hline $156 \mathrm{R}-3,70-74$ & $\begin{array}{l}1476.68 \\
\end{array}$ & 0.707464 & 0.000005 & 0.708965 & 0.000004 & 296.5 & 6.2 \\
\hline $162 \mathrm{R}-1,15-19$ & 1531.15 & 0.707547 & 0.000004 & 0.709019 & 0.000004 & 92.0 & 4.2 \\
\hline SW-1 & & $0.7013+1$ & & 0.709177 & 0.000004 & & \\
\hline SW-2 & & $\overline{-}$ & & 0.709144 & 0.000005 & & \\
\hline SW- 3 & & - & & 0.709172 & 0.000004 & & \\
\hline SW-4 & & - & & 0.709168 & 0.000004 & & \\
\hline SW-5 & & - & & 0.709173 & 0.000004 & & 7.2 \\
\hline
\end{tabular}

Notes: Identification of samples include ODP borehole, core and section numbers, interval down section in $\mathrm{cm}$, and depth below seafloor in meters to the top of the sampled interval. $\mathrm{CC}$ indicates core-catcher samples. ${ }^{87} \mathrm{Sr} /{ }^{86} \mathrm{Sr}$ values of the carbonates \pm analytical errors (one standard deviation internal precision), ${ }^{87} \mathrm{Sr} /{ }^{86} \mathrm{Sr}$ values of the pore-waters \pm analytical errors (one standard deviation internal precision). Sr concentrations in the carbonates, and $\mathrm{Sr}$ concentration in the pore waters are also given. Carbonate ${ }^{8 /} \mathrm{Sr} /{ }^{86} \mathrm{Sr}$ values were measured on squeeze cake samples, unless marked by * to indicate that the sample was a rock chip. † indicates sample splits that were dipped into distilled water before being wiped with paper towels. 
Table 3. Modern seawater ${ }^{87} \mathrm{Sr} /{ }^{86} \mathrm{Sr}$ values ${ }^{\mathrm{a}}$ that have been reported in the literature.

\begin{tabular}{llll}
\hline $\begin{array}{c}\text { Measured } \\
\text { value }\end{array}$ & \multicolumn{1}{c}{ SRM } & Normalized & \multicolumn{1}{c}{ Reference } \\
\hline 0.709163 & 0.71024 & 0.709173 & Nelson et al., 1991 \\
0.709160 & 0.71024 & 0.709170 & Nelson et al., 1991 \\
0.709110 & 0.71014 & 0.709220 & Burke et al., 1982 \\
0.709187 & 0.71026 & 0.709177 & Elderfield, 1986 \\
0.709185 & 0.710220 & 0.709215 & Hess et al., 1986 \\
0.709177 & 0.710250 & 0.709177 & UNC: Coleman, pers. comm., 1991 \\
0.709175 & 0.710250 & 0.709175 & UNC: Coleman, pers. comm., 1991 \\
0.709234 & 0.71031 & 0.709174 & DePaolo and Ingram, 1985 \\
0.70907 & 0.71014 & 0.709180 & Burke et al., 1982 \\
0.709175 & 0.710235 & 0.709190 & Hodell et al., 1989 \\
0.709238 & 0.710275 & 0.709213 & Palmer and Elderfield, 1985 \\
\hline
\end{tabular}

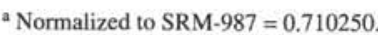

${ }^{b}$ Indicates modem seawater values that have been inferred from measurement on modern shell material.

waters are $-0.17 \%$ SMOW (Craig and Gordon, 1965). Core samples from the pelagic cap at Holes $865 \mathrm{~A}, 865 \mathrm{~B}$, and $865 \mathrm{C}$ lack internal cohesion and experienced liquefaction during the splitting process (Sager, Winterer, Firth, et al., 1993). The $\delta^{18} \mathrm{O}$ value of a sample of surface seawater was measured as $0.2 \%$ SMOW.

The distribution of pore-water $\delta^{18} \mathrm{O}$ values shows a consistent pattern (Fig. 3). Samples from 129.95 to $134.95 \mathrm{~m}$ near the base of the pelagic cap have values similar to those of seawater, which currently surrounds the guyot $(-0.1 \pm 0.15)$, while samples that are higher in the section (8.30-120.45 m) have a mean value of $0.42 \pm 0.20 \%$ SMOW and thus are distinct from the seawater surrounding the guyot.

\section{Borehole Temperatures}

The measured borehole temperatures in Sites 865 and 866 (Sager, Winterer, Firth, et al., 1993) show positive temperature gradients down both holes that start at about $3^{\circ}$ and $4^{\circ} \mathrm{C}$ at the seafloor and increase at an average rate of $0.64^{\circ} \mathrm{C} / 100 \mathrm{~m}$ in Hole $865 \mathrm{~A}$ and $0.81^{\circ} \mathrm{C} / 100 \mathrm{~m}$ in Hole $866 \mathrm{~A}$, to reach maximum values of $8.55^{\circ} \mathrm{C}$ and $13.6^{\circ} \mathrm{C}$ in Holes $865 \mathrm{~A}$ and $866 \mathrm{~A}$, respectively (Fig. 4). The measurements in Hole 865A indicate that distinct changes occurred in the temperature gradient at the break between the shallow-water carbonates and the pelagic cap (about $139 \mathrm{mbsf}$ ) and another change occurred at about $600 \mathrm{mbsf}$ in the middle of the shallow-water carbonate facies (Fig. 4). The lower temperature gradient corresponds to a very porous zone (139-600 mbsf). The waters are nearly isothermal in this interval. The temperature profile in Site 866 shows less significant changes in slope across its porous zone (Fig. 4).

These holes were flushed with seawater (the drilling fluid) during coring. The temperature of the surface seawater that was used during drilling decreased during its flow through the drill string to the seafloor and was close to bottom-water temperatures at the time it entered the hole. In this area of the Pacific (Reed, 1969), bottom-water temperatures are $3^{\circ}$ and $4^{\circ} \mathrm{C}$, respectively, for Sites 865 and 866 . Thus, these measurements are minimum estimates of formation temperatures. Because the borehole temperatures increase with depth, these data indicate that the temperatures in the interior of these guyots are distinctly warmer than that of the seawater in the surrounding ocean waters (Fig. 4)

\section{DISCUSSION}

\section{Strontium Isotopes from Carbonate Samples}

The carbonate samples from Sites 865 and 866 have ${ }^{87} \mathrm{Sr} /{ }^{86} \mathrm{Sr}$ values that are generally consistent with known variations for sedimentary carbonates through the Cenozoic and latest Mesozoic (Fig. 5). The chronostratigraphic significance of these data in the mid-Cretaceous limestone has been considered separately (Jenkyns et al., this volume).

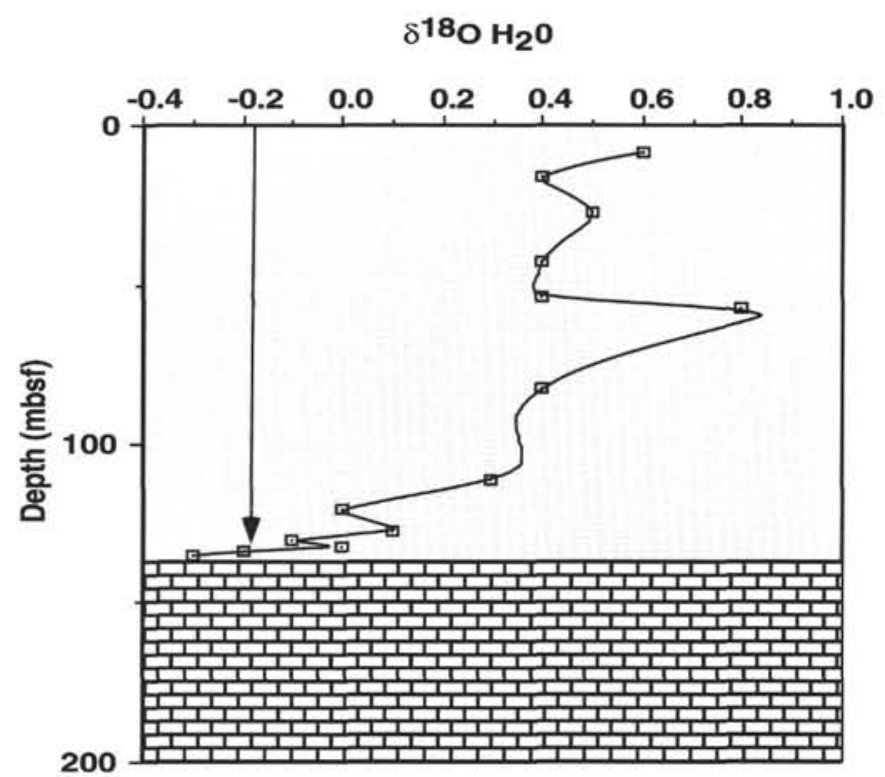

Figure $3 . \delta^{18} \mathrm{O}$ values that were measured in the waters from the Allison Guyot pelagic carbonates of Hole 865B vs. depth below seafloor. Sample spacing was closest in the lowermost section of these oozes, which are directly above the lithified carbonates. The average value of modern seawater (after Craig and Gordon, 1965) is indicated with an arrow. Note that the lowermost samples are isotopically indistinguishable from the seawater that surrounds these guyots $(-0.17) 0.10 \%$ SMOW), while the samples at higher levels have heavier isotopic values that are distinct from modem Pacific waters.

All the pelagic-cap samples from Allison and Resolution guyots are Tertiary in age (Sager, Winterer, Firth, et al., 1993). The ${ }^{87} \mathrm{Sr} /{ }^{86} \mathrm{Sr}$ values of these samples are in close agreement with published ${ }^{87} \mathrm{Sr} /{ }^{86} \mathrm{Sr}$ values for the Tertiary (e.g., Burke et al., 1982) and even confirm that a subtle maximum in ${ }^{87} \mathrm{Sr} /{ }^{86} \mathrm{Sr}$ isotopic values occurs in the Paleocene (Fig. 5A)

All the ${ }^{87} \mathrm{Sr} /{ }^{86} \mathrm{Sr}$ values from the shallow-water carbonates between 144.8 and $719.1 \mathrm{mbsf}$ in Hole $865 \mathrm{~A}$ are similar $(0.707466 \pm 0.000050$, $n=52)$ and do not indicate any significant stratigraphic trend over this interval (Fig. 2A). Paleontologic data suggest that these rocks are Aptian/Albian in age (Sager, Winterer, Firth, et al., 1993), which is not a period that has been associated with significant stratigraphic variations in ${ }^{87} \mathrm{Sr} /{ }^{86} \mathrm{Sr}$ values (Burke et al., 1982; Fig. 5A). However, the strontium isotope data are consistent with these strata having been deposited during the late Aptian to middle Albian.

The lowest three samples from Site 865 came from within $63 \mathrm{~m}$ of the basaltic basement and contain significant amounts $(6 \%-18 \%)$ of noncarbonate material. The Sr-enriched and isotopically light strontium in these samples probably indicates the influence of fluids from the basement rocks on the diagenesis of these samples or that some of it came from noncarbonate minerals (e.g., clays) during the acidification process used to extract $\mathrm{Sr}$ from the solid-phase. Thus, the stratigraphic significance of the ${ }^{87} \mathrm{Sr} /{ }^{86} \mathrm{Sr}$ values in these lower three solidphase samples from Hole $865 \mathrm{~A}$ is questionable.

The ${ }^{87} \mathrm{Sr} /{ }^{86} \mathrm{Sr}$ values of the shallow-water carbonates between 483.11 and $1531.15 \mathrm{mbsf}$ at Site 866 vary from 0.707291 to 0.708850 and have a mean value of $0.707529 \pm 0.000339$. The range of ${ }^{87} \mathrm{Sr} /{ }^{86} \mathrm{Sr}$ values (Fig. 5) is consistent with the projected stratigraphic range of these samples (Jenkyns et al., this volume).

Although the age of the Cretaceous samples from Sites 865 and 866 is not tightly controlled, the ${ }^{87} \mathrm{Sr} /{ }^{86} \mathrm{Sr}$ values of these samples are restricted to a small range within the broader field of published midCretaceous ${ }^{87} \mathrm{Sr} /{ }^{86} \mathrm{Sr}$ values (Fig. 5). There is no indication in the strontium isotopic values that the host carbonates are altered by ex- 
change with younger fluids (e.g., Richter and DePaolo, 1987; Swart et al., 1987; Saller and Koepnick, 1990; Quinn et al., 1991). Most of the diagenetic alteration that is observed in thin sections (Sager, Winterer, Firth, et al., 1993; Röhl et al., this volume) must have occurred during the early history of these guyots.

\section{Difference in ${ }^{87} \mathrm{Sr} /{ }^{86} \mathrm{Sr}$ Values Between Sediments and Pore Waters}

No close relationship between ${ }^{87} \mathrm{Sr} /{ }^{86} \mathrm{Sr}$ values of pore waters and sediments exists in either the pelagic or shallow-water carbonate facies (Figs. 2 and 5). The pore-water ${ }^{87} \mathrm{Sr} /{ }^{86} \mathrm{Sr}$ values are not strongly controlled by the ${ }^{87} \mathrm{Sr} /{ }^{86} \mathrm{Sr}$ values of their host carbonates. Thus, the resident pore waters are not the primary connate fluids that were captured in these carbonates at deposition.

\section{Source of Pore Waters}

The ${ }^{87} \mathrm{Sr} /{ }^{86} \mathrm{Sr}$ values, $\delta^{18} \mathrm{O}$ values, borehole temperature profiles, and lithologic data indicate that the fluid movement rates and chemical characteristics of these pore waters vary between the major hydrogeologic units within these guyots. Thus, the evidence for fluid circulation is discussed separately for each major lithologic and/or hydrologic unit.

\section{Pelagic Cap}

Measurements of the ${ }^{87} \mathrm{Sr} /{ }^{86} \mathrm{Sr}$ values of the pore waters that were extracted from the pelagic-cap samples from Holes $865 \mathrm{~B}$ and $866 \mathrm{~A}$ and from seawater samples collected during Leg 143 are similar $(0.709123 \pm 0.000056[n=19]$ and $0.709167 \pm 0.000012[n=5]$, respectively). Therefore, the rate of seawater exchange with the pore waters in the pelagic cap is greater than the detection limits of the strontium isotopes as a tracer. Because the ${ }^{87} \mathrm{Sr} /{ }^{86} \mathrm{Sr}$ value of seawater has increased by 0.00006 during the last million years (DePaolo and Ingram, 1985; Capo and DePaolo, 1990), these interstitial waters cannot have been isolated from seawater for more than a million years. Thus, on the basis of the $\mathrm{Sr}$ isotopic data, the pore waters in the pelagic cap and in seawater came into $\mathrm{Sr}$ isotopic equilibrium in less than a million years.

$\delta^{18} \mathrm{O}$ data indicate that faster equilibration rates of pore fluids occur in the pelagic-cap sediments than the minimum rate that was indicated by the ${ }^{87} \mathrm{Sr} /{ }^{86} \mathrm{Sr}$ data. The $\delta^{18} \mathrm{O}$ values of the pore waters from the base of the pelagic-cap section cored in Hole $865 \mathrm{~B}$ are indistinguishable from modern seawater (Fig. 3). These data suggest that the waters in the porous shallow-water carbonates directly beneath the pelagic sediments are in contact with Holocene seawater. Higher in the hole, away from the shallow-water limestone contact, the $\delta^{18} \mathrm{O}$ values increase from modern seawater values toward more positive values that are distinct from those of modern seawater. The waters in the upper $110 \mathrm{~m}$ of the pelagic cap apparently have been isolated within the sediment column for a longer time than those near the base of the pelagic cap (110-135 mbsf). No gradient was observed in the $\delta^{18} \mathrm{O}$ values of the pore-water samples at the top of the pelagic section; however, the sample spacing may be inadequate to resolve seafloor gradients.

Variations in pore-water $\delta^{18} \mathrm{O}$ values may arise as a consequence of diagenesis (Clayton et al., 1966). However, over the time periods that diagenesis is likely to operate, diffusion would erase the observed differences (e.g., Schrag and DePaolo, 1993).

The pore-water $\delta^{18} \mathrm{O}$ values in the upper part of the pelagic cap are consistent with the expected range of values that would have occurred during times of greater global ice volumes. The isotopic values of the waters that are at the base of the pelagic cap were in equilibrium with seawater less than 10,000 yr ago, after the Wisconsin glaciation (Mix, 1987). We infer that relatively modern seawater (Holocene) is entering the pelagic cap from below, out of the underlying porous shallow-

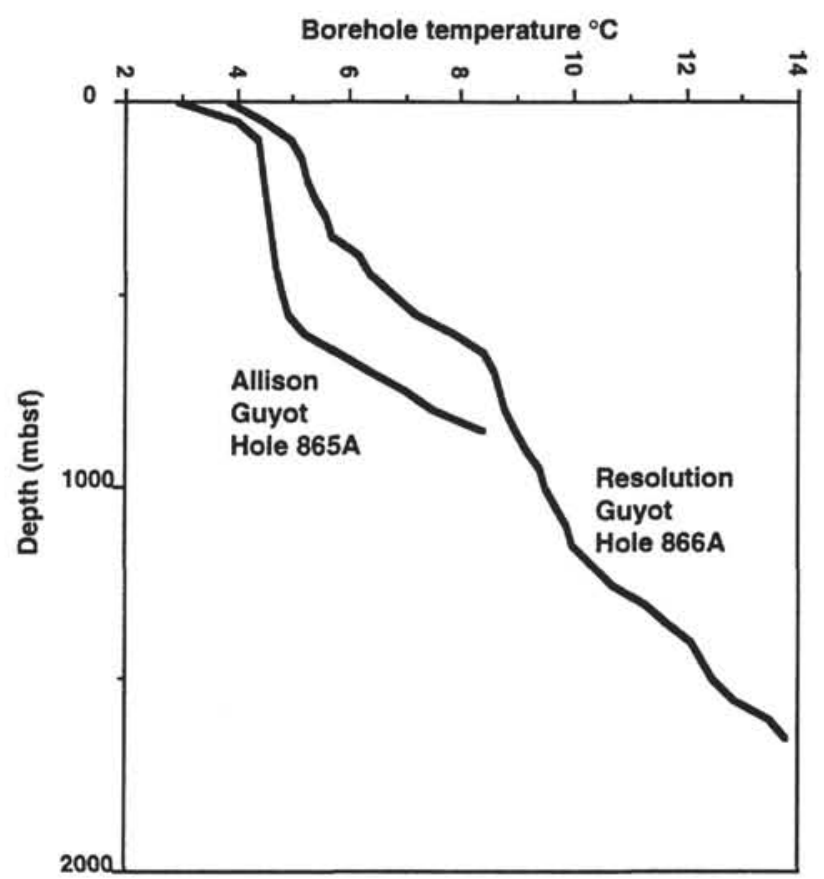

Figure 4. Borehole temperatures in Holes $865 \mathrm{~A}$ and $866 \mathrm{~A}$ from the borehole temperature logs.

water limestones. While modern seawater may only be penetrating into the pelagic cap at diffusive rates, pore-water $\delta^{18} \mathrm{O}$ values suggest that the underlying platformal carbonates are well flushed with Holocene seawater.

\section{Porous Upper Units of the Platform Limestones}

Sample recovery was too low to provide enough samples for pore-water analysis of the uppermost shallow-water limestone sections at either Sites 865 or 866 . However, pore-water $\delta^{18} \mathrm{O}$ data indicate that the pelagic cap at Site 865 was being infused from below with Holocene seawater. These data strongly suggest that an active fluid circulation cell exists beneath the pelagic cap (within the porous shallow-water limestones) at Site 865.

Borehole temperature logs from Allison (Hole 865A) and Resolution (Hole $866 \mathrm{~A}$ ) guyots show that downhole temperatures increase at an average rate of $6.4^{\circ} \mathrm{C} / \mathrm{km}$ in Hole $865 \mathrm{~A}$ and $8.1^{\circ} \mathrm{C} / \mathrm{km}$ in Hole $866 \mathrm{~B}$. Thermal differences between the geothermally heated pore waters within the platform and the cooler seawater outside the platform results in a lateral fluid density gradient. The existing thermal gradients provide a mechanism to stimulate upward flow within these guyots (Kohout, 1967; Kohout et al., 1977).

While the measured borehole temperatures are only minimum temperature estimates, the observed geothermal gradients are surprisingly low in comparison with other comparable sites in the region. For example, the thermal gradient in DSDP Site 465 on the Hess Rise, which is situated over crust of a similar age and geologic setting, is $49.7^{\circ} \mathrm{C} / \mathrm{km}$ (Fujii, 1981). Low borehole temperature gradients indicate the role of advective cooling of the platform. However, circulation is not vigorous enough to completely erase the thermal increases associated with regional heat flow.

An inflection in the thermal gradient in Site 865 near the base of the pelagic cap was interpreted (Sager, Winterer, Firth, et al., 1993) as inflow of seawater down the borehole. Preliminary reports suggested that underpressured conditions may have existed in these strata and that the inflow was in response to a drilling disturbance; however, it is unclear how under-pressured conditions could be sustained in such shallowly buried, poorly sealed, porous limestones. We suggest that 
A

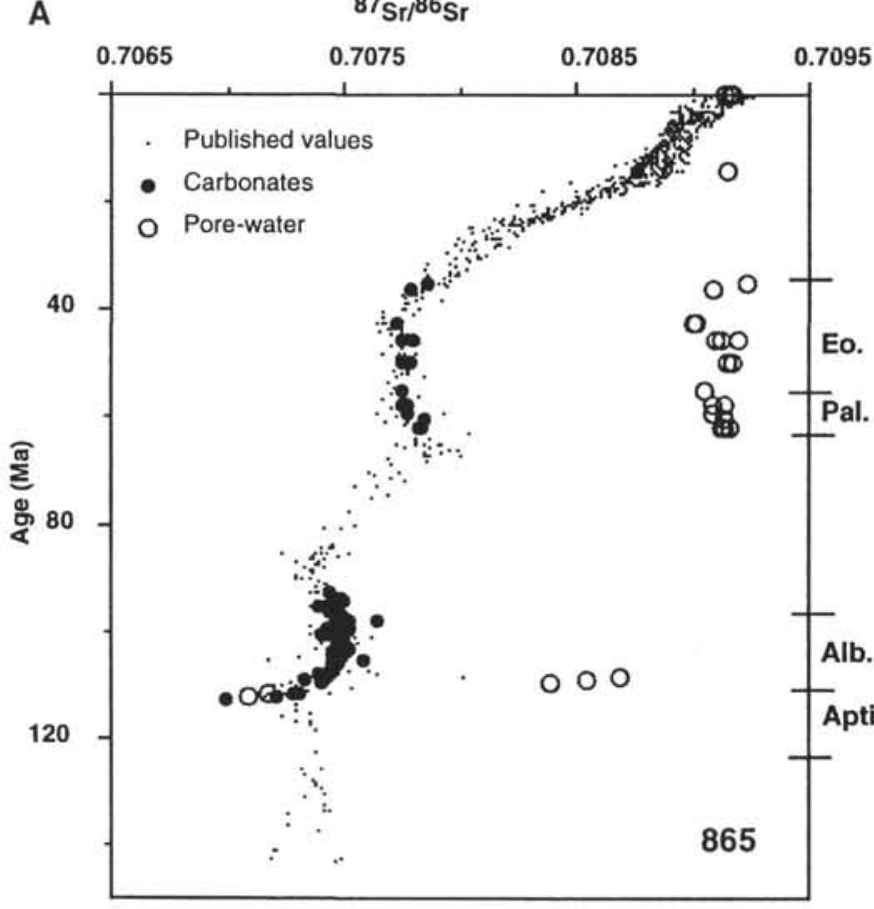

B

$87 \mathrm{Sr} / 86 \mathrm{Sr}$

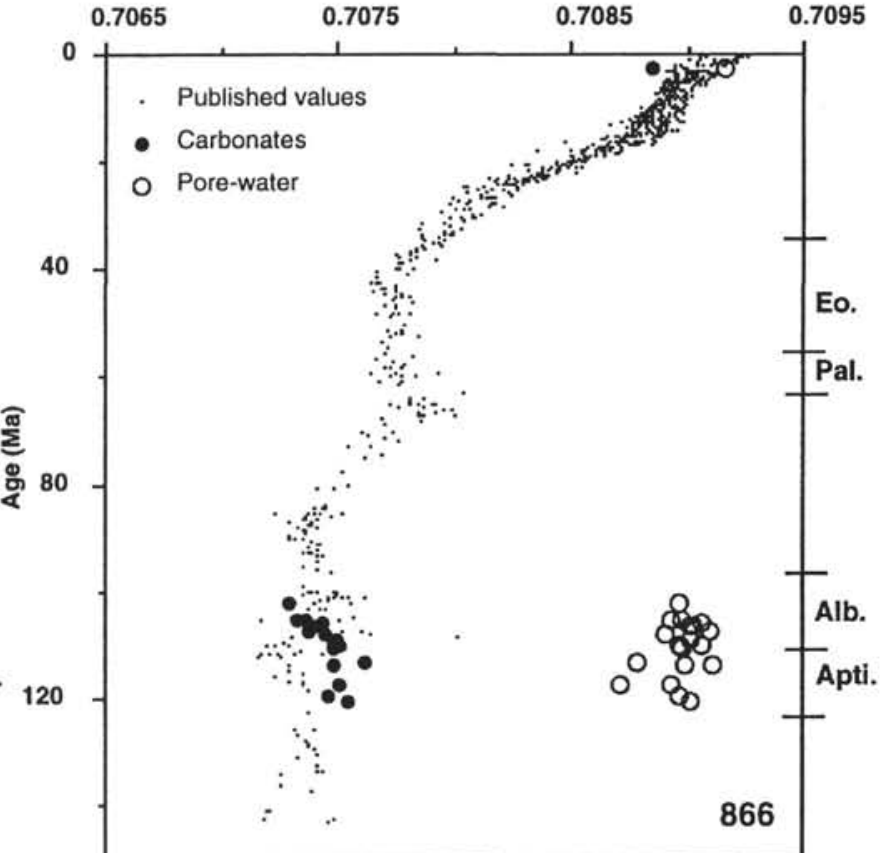

Figure $5 .{ }^{87} \mathrm{Sr} /{ }^{86} \mathrm{Sr}$ values that were measured in the carbonates (solid circles) and their waters (open circles) in Sites 865 (A) and 866 (B) vs. age. Age estimates were derived by assuming that the samples from the shallow-water carbonate sections experienced constant sedimentation rates and extended from 92.5 to 115 $\mathrm{Ma}$ in Site 865 and from 92.5 to $122 \mathrm{Ma}$ in Site 866 . Also included, as fine points, are the published values for ${ }^{87} \mathrm{Sr} /{ }^{86} \mathrm{Sr}$ measurements with age, as summarized by Jason Prosser (UNC-CH, unpubl. data). These published values define the general pattern of stratigraphic variation that is known through the last 140 m.y., although the samples have not been corrected to a common time scale. Location of Eocene (Eo.) and Paleocene (Pal.) Series and Albian (Alb.) and Aptian (Apti.) stages are given on the basis of the Harland et al. (1990) time scale.

the inflow occurs under steady-state conditions through the porous flanks of these guyots and that low temperatures and an irregular gradient existed prior to drilling. The oxygen isotopic data and the borehole temperature profiles indicate a geologically rapid fluid circulation system may exist in these extremely porous limestones.

If the thermal conditions in Allison Guyot were in steady state and the observed thermal inflection existed before drilling, there must have been a balance between the water inflow rate and the temperatures of the waters in the guyot. Because the oxygen isotopic data suggest that the upper porous zone of the shallow-water limestones at Site 865 has been flushed for the last $10,000 \mathrm{yr}$, we can evaluate the influence of seawater flushing on the thermal structure of the platform by assuming that (1) the system is in steady state; (2) seawater enters the sides of the platform at $3^{\circ} \mathrm{C}$ and is heated by at least $4^{\circ} \mathrm{C}(\Delta \mathrm{T})$ as it moves laterally through the platform (in fact, the pre-drilling temperature difference may be significantly greater); (3) the area of rapid circulation corresponds to the porous upper zone of the shallow-water carbonates (Units II and III, Sager, Winterer et al., 1993), which is 482 $\mathrm{m}$ thick, and the porosity of this unit is $25 \%$; thus, the mass $(\mathrm{m})$ that needs to be heated corresponds to a $1-\mathrm{cm}^{2}$ column of water that is 120 $\mathrm{m}$ thick ( $m=12,000 \mathrm{~g})$; (4) the heat capacity of seawater $\left(C_{p}\right)$ is 1.0026 calorie $/ \mathrm{g} /{ }^{\circ} \mathrm{C}$ at $7{ }^{\circ} \mathrm{C}$; and (5) the heat flow $(Q)$ has been estimated as $1.4 \mu \mathrm{cal} / \mathrm{cm}^{2} / \mathrm{s}$ (as the measurements from the Hess Rise; Fujii, 1981). The following relationship thus holds:

$$
t=\frac{C_{p} \Delta \mathrm{T} m}{O},
$$

where $t=$ years, which suggests that the incoming seawater can be geothermally heated $4^{\circ} \mathrm{C}$ in $2125 \mathrm{yr}$. Thus, a flushing rate that is more rapid than once per $10,000 \mathrm{yr}$ for the upper porous zones is consistent with the thermal observations. Moreover, these rates of fluid circula- tion are consistent with the rates that are thought to have occurred in other geothermally heated limestone fluid circulation cells (Kohout et al., 1977).

\section{Platform Interior Limestones}

The water samples that were taken from deeper (483-1531 m) within the interior of Resolution Guyot (Site 866) have a mean value $(0.70898 \pm 0.000097[n=27])$ that is slightly less than modern seawater. These values may reflect either (1) a mixture of modern and preQuaternary seawater, which might indicate that these deeper strata are not fully ventilated with modern seawater or (2) modern seawater into which some ancient $\mathrm{Sr}$ was added. The addition of ancient $\mathrm{Sr}$ would indicate that some $\mathrm{Sr}$ is being released from these Mesozoic carbonates into the pore fluids as a result of carbonate recrystallization or dissolution.

The $\mathrm{Sr}$ composition of the pore waters in the deeper units within the interior of these guyots may simply reflect the presence of older waters that have been trapped within this structure (i.e., mechanism 1 above). However, the ${ }^{87} \mathrm{Sr} /{ }^{86} \mathrm{Sr}$ value of seawater has been greater than the ${ }^{87} \mathrm{Sr} /{ }^{86} \mathrm{Sr}$ value in these samples since the Pliocene. These data indicate that the flushing rate in the deeper strata is at least active on a time scale of a few million years and may be much faster.

Conversely, if strontium removal from the host carbonates is assumed to be the sole cause of these small differences between pore waters and modern seawater (i.e., mechanism 2 above), the Sr budget of these rocks can be calculated. The amount of $\mathrm{Sr}$ having lighter isotope ratios that is being supplied from the dissolution of the host carbonates is given by the following relationship:

$$
\begin{gathered}
{ }^{87} \mathrm{Sr}^{86} \mathrm{Sr}_{\text {pore water }}=\left\{(1-C) \times\left({ }^{87} \mathrm{Sr}^{86} \mathrm{Sr}_{\text {seawater }}\right)\right\}+ \\
\left\{(C) \times\left({ }^{87} \mathrm{Sr} /{ }^{86} \mathrm{Sr}_{\mathrm{CaCo}_{3}}\right)\right\},
\end{gathered}
$$


where $C$ is the $\mathrm{Sr}$ contribution to the ${ }^{87} \mathrm{Sr} /{ }^{86} \mathrm{Sr}$ pool from carbonate dissolution. With the measured data, $C=11.4 \%$. Given that the mean pore-fluid Sr concentration is $7.6 \pm 1.5 \mathrm{ppm}$, only $0.9 \mathrm{ppm}$ of the porewater $\mathrm{Sr}$ needs to have been provided from the host carbonates to produce the measured ${ }^{87} \mathrm{Sr} /{ }^{86} \mathrm{Sr}$ values. Thus, the starting fluids would have only a concentration of $6.7 \mathrm{ppm} \mathrm{Sr}$. Because this concentration is slightly less than the $\mathrm{Sr}$ concentration of modern seawater, some $\mathrm{Sr}$ may have been removed elsewhere along the fluid flow path, even though the net process is that of increasing $\mathrm{Sr}$ concentrations. We cannot distinguish between mechanisms 1 and 2 (above) and suspect that both are occurring to some extent.

\section{Influence of Basement at Site 865}

The pore-water samples from deep within the shallow-water carbonates from ODP Site 865 show a trend downhole toward ${ }^{87} \mathrm{Sr} /{ }^{86} \mathrm{Sr}$ values that are slightly lighter than their host carbonates (Figs. $2 \mathrm{~A}$ and $5 \mathrm{~A})$ and $\mathrm{Sr}$ concentrations that are enriched with respect to seawater (Table 2). These samples all come from the lower part of the hole, within $191.2 \mathrm{~m}$ of the basaltic basement. A source of the $\mathrm{Sr}$ in these pore waters may be the underlying altered basalt. Pore-water ${ }^{87} \mathrm{Sr} /{ }^{86} \mathrm{Sr}$ values and $\mathrm{Sr}$ concentrations shift over the range of the five lowest pore-water samples toward seawater values uphole. These data indicate that $\mathrm{Sr}$ is being transported in fluids upward out of the basement at Site 865.

\section{Flow Patterns}

The observations described above can be explained as follows:

1. Exchange with seawater is geologically rapid $(<10,000 \mathrm{yr})$ in the extremely permeable zone near the top of the shallow-water carbonates. However, exchange of waters decreases in the deeper sections of the shallow-water carbonates to rates that may be as slow as once per a few million years. Flow could possibly extend down into the basaltic basement rocks.

2. Geothermal heating warms the waters that are in the limestone section (Kohout, 1967).

3. Warming causes these waters to be buoyant with respect to the surrounding seawater. The waters are inferred to rise and escape out of the top and sides of the guyots. If a pelagic cap is present, some of the waters percolate up through it. Thereby, the waters in the lower $30 \mathrm{~m}$ of the pelagic cap at Site 865 are most like modern seawater and become increasingly distinct above. Fluid flows probably become concentrated into more permeable channels in the upper porous limestones and the fluids move laterally to places they can escape in areas where the pelagic cap is thin or absent.

\section{Flushing Volumes}

The volume of pore water that is in the upper porous shallowwater limestone layers of these guyots can be roughly estimated assuming that this zone is approximately cylindrical in shape and that the flushing has occurred throughout this whole zone at a similar rate since the guyot drowned. The radii of both Allison and Resolution guyots are approximately $12 \mathrm{~km}$. The assumption of constant flow rates ignores the changes in the porosity, permeability, and thermal structure of these carbonates that may have occurred over this same time period. The volume of water in the porous upper zone of the shallow-water carbonates (effectively $120 \mathrm{~m}$, since Site 865 Units II and III are $482 \mathrm{~m}$ thick and have a porosity of $25 \%$; Sager, Winterer, Firth, et al., 1993) is about $5.4 \times 10^{10} \mathrm{~m}^{3}$. Thus, more than $54 \mathrm{~km}^{3}$ of water can be inferred to have passed through these upper layers of Allison Guyot in the last $10,000 \mathrm{yr}$. If circulation has continued at the same rate at Allison Guyot for the approximately 92 million years since it drowned, then more than $5 \times 10^{5} \mathrm{~km}^{3}$ of water may have flushed through the upper porous layers of these shallow-water car- bonates. However, these flushing rates do not require flow velocities of more than a few meters per year.

\section{Geochemical Consequences of Flow}

\section{Diagenesis}

The circulation pathways outlined above and indicated in Figure 1 suggest that pore waters experience changing geochemical conditions as they pass through the guyots. Providing magnesium for dolomitization would not be a problem in these guyots (Flood et al., this volume).

\section{Cementation and Corrosion}

Carbonate solubilities in natural waters decrease with increasing temperatures and increase with decreasing pressure (Morse and Mackenzie, 1990). Variations in the saturation state will occur as a consequence of temperature and pressure changes along the flow paths. For example, waters flowing into the flanks of these guyots will not necessarily be associated with a change in depth ( pressure), but will experience a significant change in temperature as they are geothermally warmed. Corrosion, and thus an increase in porosity, could occur along the deep flanks of the guyots, as deep waters undersaturated in calcite enter the guyot. As the waters become warmer, the effect will be a decrease in the degree of under-saturation of calcite in the infiltrating water. Thus, cements then could be generated along the incoming flow paths. Conversely, when the waters cool upon leaving the guyots, the waters will dissolve carbonate in an attempt to maintain equilibrium. The effects of corrosion should be greatest near the tops of the permeable sections, especially where escaping pore-water flows are concentrated and where the cooling is most rapid. Corrosion may further enhance subsurface flow by opening secondary porosity along productive conduits.

While the short-term corrosion effects associated with either temperature, pressure or mixing modification of circulating water are slight, the volumes of waters that are suggested to have passed through the upper sections of these guyots are enormous. Thus, the circulation system that has been outlined in this paper may be partly responsible for the development of the high porosity within these drowned carbonate platforms and for the corrosion of the upper surfaces of these guyots.

To illustrate the potential amount of carbonate that could be removed by corrosion associated with fluid flow, we have arbitrarily assumed that there is a net increase of $10 \mu \mathrm{M}$ in the carbonate content of the flushing waters (as a result of limestone dissolution) as they leave the guyot. This increase in the carbonate ion concentration would not be analytically detectible from the 2300 to $2400 \mu \mathrm{M}$ range that is associated with North Pacific Deep Water (Takahashi et al., $1980)$. Using the molecular weight $(\sim 100 \mathrm{~g} / \mathrm{mole})$ and density of calcite $\left(2.72 \mathrm{~g} / \mathrm{cm}^{3}\right)$, one can calculate that each liter of water will carry away $3.7 \times 10^{-4} \mathrm{~cm}^{3}$ of calcite, and thus the $5 \times 10^{5} \mathrm{~km}^{3}$ of water that may have passed through these structures would remove $1.8 \times$ $10^{14} \mathrm{~cm}^{3}$ or $0.18 \mathrm{~km}^{3}$ of calcite. This is about $1 \%$ of the volume in the most actively circulating part of these guyots (assuming a radius of $12 \mathrm{~km}$ and a $482-\mathrm{m}$-thick active section). If this amount of corrosion is concentrated in particular areas, this process could significantly alter the shape of the upper surface and the porosity and permeability structure of the carbonate shallow-water carbonates of these guyots.

\section{CONCLUSIONS}

1. Sr isotopic values of the solid phases are similar to published values for samples of the same general age.

2. $\mathrm{Sr}$ isotopic values and concentrations in pore waters from Holes $865 \mathrm{~A}, 865 \mathrm{~B}$, and $866 \mathrm{~A}$ are generally similar to seawater. These values indicate that most of these platforms are flushed by fresh seawater more rapidly then once per million years. Without any dia- 
genetic influx, the $\mathrm{Sr}$ isotopic content of these waters is similar to seawater less than $5 \mathrm{Ma}$ old.

3. Sr isotopic values of the host carbonates do not exert a significant influence on the composition of their contained pore waters, except possibly in the deepest part of Hole 865. Conversely, the solid-phase $\mathrm{Sr}$ isotope values of these samples were not significantly reset by late stage (Neogene) diagenesis.

4. The pelagic-cap carbonate samples have $\mathrm{Sr}$ concentrations about three times greater than the underlying lithified shallow-water limestones.

5. Low Sr isotopic values in Hole $865 \mathrm{~A}$ indicate that the basement rocks are affecting the composition of both carbonates and pore waters.

6. Oxygen isotopic values of the pore waters from the base of the pelagic cap are similar to those of modern seawater. These data indicate that the circulation is most active in the base of the pelagic cap that directly overlies the uppermost sections of the lithified shallow-water carbonates and decreases upward into the 139-m-thick pelagic-cap section at Site 865 . For these waters to be similar to modern seawater implies that these fluids have been in contact with the surrounding oceanic waters within the last $10,000 \mathrm{yr}$.

7. Large volumes $\left(\sim 100,000 \mathrm{~km}^{3}\right)$ of seawater are estimated to have passed through these drowned carbonate platforms over the last 92 m.y.

8. A generalized pattern of fluid circulation was constructed for these guyots by splicing together data from Sites 865 and 866: (1) seawater invades through the flanks of these guyots into the permeable shallow-water limestones and to a lesser extent the basaltic core of these guyots; (2) pore waters undergo geothermal heating, which results in buoyant upward flow; (3) waters are inferred to discharge through the top of the guyots; where thick sequences of pelagic sediments are present, they may act as an aquiclude and deflect upward flow laterally toward discharging conduits (Fig. 1).

9. With large fluxes of water, considerable changes in the porosity and permeability structures of these platforms and even the surface topography of these guyots could exist.

\section{ACKNOWLEDGMENTS}

Funding from JOI-USSAC and the Deutsche Forshungsgemeinschaft (DFG) supported this work. We thank Chieh Peng and Ken McCormack for help at sea and John Cargill for his assistance with processing samples for $\mathrm{Sr}$ isotopic analysis. The manuscript benefitted from discussions with William Ussler and Walter Borowski and reviews from Paul Baker and Peter Swart.

\section{REFERENCES}

Aharon, P., Socki, R.A., and Chan, L., 1987. Dolomitization of atolls by seawater convection flow: test of a hypothesis at Niue, South Pacific. J. Geol., 95:187-203.

Baker, P.A., Stout, P.M., Kastner, M., and Elderfied, H., 1991. Large-scale lateral advection of seawater though oceanic crust in the central equatorial Pacific. Earth Planet. Sci. Lett., 105:522-533.

Bathurst, R.G.C., 1975. Carbonate Sediments and Their Diagenesis. Developments in Sedimentology, 12: Amsterdam (Elsevier).

Brass, G.W., 1976. The variation of the marine ${ }^{87} \mathrm{Sr}^{86} \mathrm{Sr}$ ratio during Phanerozoic time: interpretations using a flux model. Geochem. Cosmochim. Acta, 40:721-730.

Burke, W.H., Denison, R.E., Hetherington, E.A., Koepnick, R.B., Nelson, H.F., and Otto, J.B., 1982. Variation of seawater ${ }^{87} \mathrm{Sr} /{ }^{86} \mathrm{Sr}$ throughout Phanerozoic time. Geology, 10:516-519.

Capo, R.C., and DePaolo, D.J., 1990. Seawater strontium isotopic variations from 2.5 million years ago to the present. Science, 249:51-55.

\footnotetext{
Abbreviations for names of organizations and publications in ODP reference lists follow the style given in Chemical Abstracts Service Source Index (published by American Chemical Society).
}

Clayton, R.N., Friedman, I., Graf, D.L., Mayeda, T.K., Meents, W.F., and Shimp, N.F., 1966. The origin of saline formation waters: I. Isotopic composition. J. Geophys. Res., 71:3869-3882.

Craig, H., and Gordon, L.I., 1965. Deuterium and oxygen-18 variations in the ocean and the marine atmosphere. In Tongiorgi, E. (Ed.), Stable Isotopes in Oceanographic Studies and Paleotemperatures: Pisa (Consiglio Nazionale), 9-130.

DePaolo, D.J., and Ingram, B.L., 1985. High-resolution stratigraphy with strontium isotopes. Science, 227:938-941.

Dunham, R.J., 1969. Early vadose silt in Townsend mound (reef), New Mexico. In Friedman, G.M. (Ed.), Depositional Environments in Carbonate Rocks: A Symposium. Spec. Publ.-Soc. Econ. Paleontol. Mineral., 14:131-181.

Edmond, J.M., Chung, Y., and Sclater, J.G., 1971. Pacific bottom water: penetration east around Hawaii. J. Geophys. Res., 76:8089-8097.

Elderfield, H., 1986. Strontium isotope stratigraphy. Palaeogeogr., Palaeoclimatol., Palaeoecol., 57:71-90.

Elderfield, H., and Gieskes, J.M., 1982. Sr isotopes in interstitial waters of marine sediments from Deep Sea Drilling Project cores. Nature, 300:493497.

Elderfield, H., Swart, P.K., McKenzie, J.A., and Williams, A., 1993. The strontium isotopic composition of pore waters from Leg 133: northeast Australian margin. In McKenzie, J.A., Davies, P.J., Palmer-Julson, A., et al., Proc. ODP, Sci. Results, 133: College Station, TX (Ocean Drilling Program), 473-480.

Epstein, S., and Mayeda, T., 1953. Variation of ${ }^{18} \mathrm{O}$ content of waters from natural sources. Geochim. Cosmochim. Acta, 4:213-224.

Fujii, N., 1981. Down-hole temperature measurements and heat flow at Hess Rise, Deep Sea Drilling Project Leg 62. In Thiede, J., Vallier, T.L., et al., Init. Repts. DSDP, 62: Washington (U.S. Govt. Printing Office), 1009-1013.

Harland, W.B., Armstrong, R.L., Cox, A.V., Craig, L.E., Smith, A.G., and Smith, D.G., 1990. A Geologic Time Scale 1989: Cambridge (Cambridge Univ. Press).

Hess, J. Bender, M.L., and Schilling, J.G., 1986. Evolution of the ratio of strontium-87 to strontium-86 in seawater from Cretaceous to Present. Science, 231:979-984.

Hodell, D.A., Mueller, P.A., McKenzie, J.A., and Mead, G.A., 1989. Strontium isotope stratigraphy and geochemistry of the late Neogene ocean. Earth Planet. Sci. Lett., 92:165-178.

Kohout, F.A., 1967. Groundwater flow and the geothermal regime of the Floridian Plateau. Trans. Gulf Coast Assoc. Geol. Soc., 17:339-354.

Kohout, F.A., Henry, H.R., and Banks, J.E., 1977. Hydrogeology related to geothermal conditions of the Floridian Plateau. In Smith, D.L., and Griffin, G.M. (Eds.), The Geothermal Nature of the Floridian Plateau. Spec. Publ.-Fla. Bur. Geol., 21:1-41.

Ladd, H.S., and Schlanger, S.O., 1960. Drilling operation on Enewetak Atoll. Geol. Surv. Prof. Pap. U.S., 260Y:863-905.

Ludwig, K.R., Halley, R.B., Simmons, K.R., and Peterman Z.E., 1988. Strontium-isotope stratigraphy of Enewetak Atoll. Geology, 16:173-177.

Manheim, F.T., and Horn, M.K., 1968. Composition of deeper subsurface waters along the Atlantic continental margin. Southeast. Geol., 9:215-236.

Mix, A.C., 1987. The oxygen-isotope record of glaciation. In Ruddiman, W.F., and Wright, H.E., Jr. (Eds.), North America and Adjacent Oceans During the Last Glaciation. Boulder, CO (Geol. Soc. Am.), K-3:111-125.

Morse, J.W., and Mackenzie, F.T., 1990. Geochemistry of Sedimentary Carbonates. Developments in Sedimentology, 48: Amsterdam (Elsevier).

Nelson, B.K., MacLeod, G.K., and Ward, P.D., 1991. Rapid change in strontium isotopic composition of sea water before the Cretaceous/Tertiary boundary. Nature, 351:644-647.

Palmer, M.R., and Elderfield, H., 1985. Sr isotope composition of seawater over the past 75 million years. Nature, 314:526-528.

Quinn, T.M., Lohmann, K.C., and Halliday, A.N., 1991. Sr isotopic variation in shallow water carbonate sequences: stratigraphic, chronostratigraphic, and eustatic implications of the record at Enewetak Atoll. Paleoceanography, 6:371-385.

Reed, R.K., 1969. Deep-water properties and flow in the central north Pacific. J. Mar. Res., 27:24-31.

Richter, F.M., and DePaolo, D.J., 1987. Numerical models for diagenesis and the Neogene $\mathrm{Sr}$ isotopic evolution of seawater from DSDP Site 590B. Earth Planet. Sci. Lett., 83:27-38.

Roden, G.I., 1987. Effects of seamount chains on ocean circulation and thermocline structure. In Keating, B.H., Fryer, P., Batiza, R., and Boehlert, G.W. (Eds.), Seamounts, Islands and Atolls, Geophys. Monogr. Am. Geophys. Union, 43:335-354. 
Rougerie, F., and Wauthy, B., 1990. Les atolls oasis. Recherche, 21:834-842.

Sager, W.W., Winterer, E.L., Firth, J.V., et al., 1993. Proc. ODP, Init. Repts., 143: College Station, TX (Ocean Drilling Program).

Saller, A.H., and Koepnick, R.B., 1990. Eocene to early Miocene growth of Enewetak Atoll: insight from strontium isotope data. Geol. Soc. Am. Bull., 102:381-390.

Schrag, D.P., and DePaolo, D.J., 1993. Determination of $\delta^{18} \mathrm{O}$ of seawater in the deep ocean during the last glacial maximum. Paleoceanography, 8:1-6.

Shackleton, N.J., and Opdyke, N.D., 1973. Oxygen isotope and paleomagnetic stratigraphy of equatorial Pacific core V28-238: oxygen isotope temperatures and ice volumes on a $10^{5}$ year and $10^{6}$ year scale. Quat. Res., 3:39-55.

Swart, P.K., Ruiz, J., and Holmes, C.W., 1987. Use of strontium isotopes to constrain the timing and mode of dolomitization of upper Cenozoic sediments in a core from San Salvador, Bahamas. Geology, 15:262-265.

Swartz, J.H., 1958. Geothermal measurements on Enewetak and Bikini Atolls: Bikini and nearby Atolls. Geol. Surv. Prof. Pap. U.S., 260-U:711-739.
Takahashi, T., Broecker, W.S., Bainbridge, A.E., and Weiss, R.F., 1980. Carbonate Chemistry of the Atlantic, Pacific, and Indian Oceans: The Results of the GEOSEC Expeditions, 1972-1978. Lamont-Doherty Geol. Observ. Tech. Rep. 1, CV-1-80.

Whitaker, F.F., and Smart, P.L., 1990. Active circulation of saline ground waters in carbonate platforms: evidence from the Great Bahama Bank. Geology, 18:200-203.

Wong, W.W., and Klein, P.D., 1986. A review of the techniques for the preparation of biological samples for mass-spectrometric measurements of hydrogen-2/hydrogen-1 and oxygen-18/oxygen-16 isotope ratios. Mass Spectrom. Rev., 5:313-342.

Date of initial receipt: 21 June 1993

Date of acceptance: 6 July 1994

Ms 143SR-222 